\title{
Occupational injury rates in personnel of emergency medical services
}

\author{
Robert Gałązkowski', Aneta Binkowska ${ }^{1,2}, K^{1}$ rzysztof Samoliński ${ }^{3}$ \\ ${ }^{1}$ Department of Emergency Medical Services, Medical University, Warsaw, Poland \\ ${ }^{2}$ Department of Medicine of Disasters, Medical University, Warsaw, Poland \\ ${ }^{3}$ Department of Public Health, Medical University, Warsaw, Poland
}

Gałązkowski R, Binkowska A, Samoliński K. Occupational injury rates in personnel of emergency medical services. Ann Agric Environ Med. 2015; 22(4): 680-684. doi: 10.5604/12321966.1185775

\begin{abstract}
Introduction and objectives. The system of emergency medical services (EMS) in Poland was established in 2006. The risk of occupational injuries to EMS personnel is very high, irrespective of the country where they operate, as they face many hazards in their everyday work. The aim of this study is to describe the type, incidence and consequences of occupational accidents among the personnel of the National Emergency Medical Services in Poland (NEMS - land and air ambulance crews) in 2008-2012.

Material and methods. The study reviewed all occupational accidents among the EMS personnel reported to the National Labour Inspectorate in 2008-2012.

Results. In the period reported, the number of accidents decreased from 32 in 2008 to just 6 in 2012. Traffic accidents predominated and most of the victims were male paramedics under 30 years of age. The most common injuries included multiple organ injuries and injuries of the cervical spine, chest and trunk.

Conclusions. The growing professional experience of the EMS personnel has a beneficial effect on occupational injury rates as they tend to decrease with longer employment. Occupational accidents are definitely more common among ambulance crews than in the personnel of other organizational units of the National Emergency Medical Services.
\end{abstract}

Key words

emergency medical services, occupational injury

\section{INTRODUCTION}

The system of National Emergency Medical Services (NEMS) in Poland was established by the Act on the Emergency Medical System of 8 December 2006 [1]. The main goal of the system described in the Act is to provide out-of-hospital emergency medical care. The Act regulates the organization of the NEMS system, its funding, qualifications of the medical and paramedical personnel, and other important aspects of its operations.

The NEMS personnel is obviously in everyday contact with patients, their families or witnesses of incidents, who not infrequently behave irrationally, e.g. because of extreme worry about their or their relatives' condition. Pasramedics, emergency nurses and physicians also often provide medical care in hazardous areas, irrespective of weather conditions. High levels of stress and unpredictable situations increase the likelihood of occupational accidents.

Published papers that assess the seven years of NEMS operations do not include any studies of occupational accidents among the personnel. Importantly, there is a shortage of information about the technical condition of the ambulance equipment, and no data on the incidence and causes and effects of occupational accidents among ambulance crews.

The Act on Social Insurance System against the risk of occupational accidents and diseases [2] defines an occupational accident as a 'sudden occurrence due to an

Address for correspondence: Robert Gałązkowski, Department of Emergency Medical Services, Medical University, Warsaw, Poland

E-mail: j.sochacka@lpr.com.pl

Received: 20 January 2014; accepted: 10 April 2014 external cause which leads to injury or death and is workrelated', occurs in the course of a worker's usual employment, or when carrying out duties at their employer's request or being at their employer's disposal on the way between the employer's premises and the site where work-related duties are carried out. Health care professionals are exposed to numerous hazards which may be classified into four main categories:

1. physical: overt aggression of the patients, their family members and witnesses; road traffic accidents; injuries; animal bites; electric shock; musculoskeletal sprains and strains;

2. chemical: exposure to chemical substances;

3. biological: exposure to infectious material;

4. psychophysical: mental stress associated with prompt decision-making in an acute setting when the patient's health or life may be threatened, contact with patients, patients' death, and passive aggressive behaviour of the patients and their family members.

An American study reported the occupational fatality rate among emergency medical services (EMS) personnel in the United States of $12.7 / 100,000$. This was comparable with the occupational fatality rates of police and firefighters, and more than twice as high as the rate in the general population [3]. A report of ambulance crash-related injuries in the United States in 1991-2002 found that most of the fatalities were among persons travelling in the patient compartment of ambulances (no distinction was made between patients and health care professionals). Most of the victims did not wear safety belts [4]. In their meta-analysis of air crashes in helicopter emergency medical services (HEMS), Hinkelbein 
et al. [5] found a much higher risk of crashes compared to commercial aviation, as well as differences in risk rates between the countries where the data were analysed (USA, Australia, Germany). The authors emphasized the need for a careful analysis of any incident in the operations of air medical emergency services.

In Poland, so far there have been no scientific analyses of accidents in the EMS setting which would contribute to increasing the safety of both health care professionals and patients. In spite of frequent reports of such incidents, they have not been reviewed in detail and as a result there have been no attempts to implement appropriate changes in the system to increase the safety of the NEMS personnel potentially exposed to specific work-related hazards [6].

Objective. The aim of the study was identify the type, incidence and consequences of occupational accidents in the National Medical Emergency Services personnel (land and air ambulances) in 2008-2012.

\section{MATERIALS AND METHOD}

For the purposes of this study, 72 occupational accidents in the medical emergency services setting reported to the National Labour Inspectorate in the period between 1 January 2008 31 December 2012, were reviewed. In the accidents analysed, 153 NEMS workers were involved, with 128 injured. Males accounted for $78.0 \%$ of the workers involved in the accidents and females for $22.0 \%$. Age distribution of accident victims is presented in Table 4.

The accident victims were subdivided by job title into paramedics $(45.8 \%)$, nurses (13.7\%), physicians $(7.8 \%)$, ambulance drivers (27.5\%), air ambulance pilots $(0.7 \%)$, ambulance technicians (3.3\%), others (1.3\%). For each accident, the following data were collected: year, number of people involved, type, consequences (injuries to the ambulance crew) and site of accident.

\section{RESULTS}

Nearly two-thirds of all accidents, with the resulting proportional number of casualties, occurred in $2008-2009$, but there was a wide variation in the ratio of the number of casualties to the number of accidents (Tab. 1). Traffic accidents predominated throughout the study period with
Table 2. Number of accidents and of casualties in the study period

\begin{tabular}{ccccc}
\hline & \multicolumn{4}{c}{ Incidents } \\
\cline { 2 - 5 } Year & \multicolumn{3}{c}{ Accidents } & \multicolumn{2}{c}{ Casualties } \\
\cline { 2 - 5 } & $\mathrm{N}$ & $\%$ & 67 & $52.3 \%$ \\
\hline 2008 & 32 & $44.4 \%$ & 16 & $12.5 \%$ \\
\hline 2009 & 15 & $20.8 \%$ & 22 & $17.2 \%$ \\
\hline 2010 & 10 & $13.9 \%$ & 10 & $7.8 \%$ \\
\hline 2011 & 10 & $13.9 \%$ & 13 & $10.2 \%$ \\
\hline 2012 & 5 & $6.9 \%$ & 128 & $100.0 \%$ \\
\hline Total & 72 & $100.0 \%$ &
\end{tabular}

the only exception being 2011 when trauma sustained in traffic accidents accounted for fewer than $50 \%$ of all injuries (Tab. 2). There were 5 fatalities in the study period, 3 in 2009 (all victims were NEMS workers) and 2 in 2010 (one victim was a patient).

One hundred-twenty (120) people were injured on working days and 33 people on non-working days. In 2008 alone, the average number of accidents was the same on working days and non-working days, and in the remaining years there were twice as many accidents on working days as on non-working days (Tab. 3). Most of the casualties (approximately 80\%) were males, but the proportion of females tended to increase in the last two years of the study period. Interestingly, mostly younger people were involved in the accidents (Tab. 4).

Paramedics accounted for most of the casualties (45.8\%), followed by ambulance drivers (27.5\%) and nurses (13.7\%). There were no significant differences in this respect over the study period (Tab. 5). Over $95 \%$ of all accidents occurred in ambulances, including approximately $29 \%$ in ambulances transporting a patient at the time of the incident (Tab. 6).

During the entire study period, traumas constituted the largest group, with the predominance of multiple injuries and injuries of the cervical spine, chest and trunk (Tab. 7). This is in agreement with the data presented in Table 6 confirming the predominance of traffic accidents.

Calls other than category K1 (immediately life-threatening response) accounted for more than $50 \%$ of all calls in any given year, with the exception of 2012 when $100 \%$ of calls were classified K1. In the other years covered by the study, the number of responses other than $\mathrm{K} 1$ and 'non-K1' tended to increase (Fig. 1).

Table 1. Casualties by gender and age

\begin{tabular}{|c|c|c|c|c|c|c|c|c|c|c|c|c|c|}
\hline & & \multicolumn{10}{|c|}{ Year } & \multirow{2}{*}{\multicolumn{2}{|c|}{ Total }} \\
\hline & & \multicolumn{2}{|c|}{2008} & \multicolumn{2}{|c|}{2009} & \multicolumn{2}{|c|}{2010} & \multicolumn{2}{|c|}{2011} & \multicolumn{2}{|c|}{2012} & & \\
\hline & & $\mathrm{N}$ & $\%$ & $\mathrm{~N}$ & $\%$ & $\mathrm{~N}$ & $\%$ & $\mathrm{~N}$ & $\%$ & $\mathrm{~N}$ & $\%$ & $\mathrm{~N}$ & $\%$ \\
\hline \multirow[t]{2}{*}{ Gender } & Female & 9 & $13.4 \%$ & 8 & $25.0 \%$ & 4 & $18.2 \%$ & 6 & $31.6 \%$ & 6 & $46.2 \%$ & 33 & $21.6 \%$ \\
\hline & Male & 58 & $86.6 \%$ & 24 & $75.0 \%$ & 18 & $81.8 \%$ & 13 & $68.4 \%$ & 7 & $53.8 \%$ & 120 & $78.4 \%$ \\
\hline \multirow[t]{4}{*}{ Age (years) } & $<30$ & 20 & $29.9 \%$ & 10 & $31.3 \%$ & 8 & $36.4 \%$ & 10 & $52.6 \%$ & 7 & $53.8 \%$ & 55 & $35.9 \%$ \\
\hline & $31-40$ & 17 & $25.4 \%$ & 1 & $3.1 \%$ & 3 & $13.6 \%$ & 3 & $15.8 \%$ & 2 & $15.4 \%$ & 26 & $17.0 \%$ \\
\hline & $41-50$ & 17 & $25.4 \%$ & 16 & $50.0 \%$ & 6 & $27.3 \%$ & 5 & $26.3 \%$ & 3 & $23.1 \%$ & 47 & $30.7 \%$ \\
\hline & $>51$ & 13 & $19.4 \%$ & 5 & $15.6 \%$ & 5 & $22.7 \%$ & 1 & $5.3 \%$ & 1 & $7.7 \%$ & 25 & $16.3 \%$ \\
\hline Total & & 67 & $100.0 \%$ & 32 & $100.0 \%$ & 22 & $100.0 \%$ & 19 & $100.0 \%$ & 13 & $100.0 \%$ & 153 & $100.0 \%$ \\
\hline
\end{tabular}


Table 3. Causes of injuries*

\begin{tabular}{|c|c|c|c|c|c|c|c|c|c|c|c|c|}
\hline \multirow{3}{*}{$\begin{array}{l}\text { Accident } \\
\text { type }\end{array}$} & \multicolumn{10}{|c|}{ Year } & \multirow{2}{*}{\multicolumn{2}{|c|}{ Total }} \\
\hline & \multicolumn{2}{|c|}{2008} & \multicolumn{2}{|c|}{2009} & \multicolumn{2}{|c|}{2010} & \multicolumn{2}{|c|}{2011} & \multicolumn{2}{|c|}{2012} & & \\
\hline & $\mathrm{N}$ & $\%$ & $\mathrm{~N}$ & $\%$ & $\mathrm{~N}$ & $\%$ & $\mathrm{~N}$ & $\%$ & $\mathrm{~N}$ & $\%$ & $\mathrm{~N}$ & $\%$ \\
\hline Traffic accident & 51 & $76.1 \%$ & 30 & $62.5 \%$ & 23 & $67.6 \%$ & 12 & $41.4 \%$ & 16 & $84.2 \%$ & 132 & $67.0 \%$ \\
\hline Assault with bodily harm & 2 & $3.0 \%$ & 4 & $8.3 \%$ & 4 & $11.8 \%$ & 2 & $6.9 \%$ & 0 & $0.0 \%$ & 12 & $6.1 \%$ \\
\hline Mechanical injury & 2 & $3.0 \%$ & 2 & $4.2 \%$ & 0 & $0.0 \%$ & 5 & $17.2 \%$ & 0 & $0.0 \%$ & 9 & $4.6 \%$ \\
\hline Poisoning & 4 & $6.0 \%$ & 0 & $0.0 \%$ & 0 & $0.0 \%$ & 4 & $13.8 \%$ & 0 & $0.0 \%$ & 8 & $4.1 \%$ \\
\hline Ambulance failure & 4 & $6.0 \%$ & 0 & $0.0 \%$ & 0 & $0.0 \%$ & 0 & $0.0 \%$ & 0 & $0.0 \%$ & 4 & $2.0 \%$ \\
\hline Weather conditions & 2 & $3.0 \%$ & 5 & $10.4 \%$ & 0 & $0.0 \%$ & 0 & $0.0 \%$ & 0 & $0.0 \%$ & 7 & $3.6 \%$ \\
\hline Loss of consciousness & 0 & $0.0 \%$ & 2 & $4.2 \%$ & 2 & $5.9 \%$ & 0 & $0.0 \%$ & 0 & $0.0 \%$ & 4 & $2.0 \%$ \\
\hline Other causes & 2 & $3.0 \%$ & 5 & $10.4 \%$ & 5 & $14.7 \%$ & 6 & $20.7 \%$ & 3 & $15.8 \%$ & 21 & $10.7 \%$ \\
\hline Total & 67 & $100.0 \%$ & 48 & $100.0 \%$ & 34 & $100.0 \%$ & 29 & $100.0 \%$ & 19 & $100.0 \%$ & 197 & $100.0 \%$ \\
\hline
\end{tabular}

*The number of causes exceeds the number of casualties since there may have been more than one cause of injury per one victim

Table 4. Number of casualties by day of accident

\begin{tabular}{|c|c|c|c|c|c|c|c|c|c|c|c|c|}
\hline \multirow{3}{*}{ Day } & \multicolumn{10}{|c|}{ Year } & \multirow{2}{*}{\multicolumn{2}{|c|}{ Total }} \\
\hline & \multicolumn{2}{|c|}{2008} & \multicolumn{2}{|c|}{2009} & \multicolumn{2}{|c|}{2010} & \multicolumn{2}{|c|}{2011} & \multicolumn{2}{|c|}{2012} & & \\
\hline & $\mathrm{N}$ & $\%$ & $\mathrm{~N}$ & $\%$ & $\mathrm{~N}$ & $\%$ & $\mathrm{~N}$ & $\%$ & $\mathrm{~N}$ & $\%$ & $\mathrm{~N}$ & $\%$ \\
\hline Working day & 48 & $71.6 \%$ & 26 & $81.3 \%$ & 19 & $86.4 \%$ & 16 & $84.2 \%$ & 11 & $84.6 \%$ & 120 & $78.4 \%$ \\
\hline Non-working day & 19 & $28.4 \%$ & 6 & $18.8 \%$ & 3 & $13.6 \%$ & 3 & $15.8 \%$ & 2 & $15.4 \%$ & 33 & $21.6 \%$ \\
\hline Total & 67 & $100.0 \%$ & 32 & $100.0 \%$ & 22 & $100.0 \%$ & 19 & $100.0 \%$ & 13 & $100.0 \%$ & 153 & $100.0 \%$ \\
\hline
\end{tabular}

Table 5. Casualties by job title

\begin{tabular}{|c|c|c|c|c|c|c|c|c|c|c|c|c|}
\hline \multirow{3}{*}{ Job title } & \multicolumn{10}{|c|}{ Year } & \multirow{2}{*}{\multicolumn{2}{|c|}{ Total }} \\
\hline & \multicolumn{2}{|c|}{2008} & \multicolumn{2}{|c|}{2009} & \multicolumn{2}{|c|}{2010} & \multicolumn{2}{|c|}{2011} & \multicolumn{2}{|c|}{2012} & & \\
\hline & $\mathrm{N}$ & $\%$ & $\mathrm{~N}$ & $\%$ & $\mathrm{~N}$ & $\%$ & $\mathrm{~N}$ & $\%$ & $\mathrm{~N}$ & $\%$ & $\mathrm{~N}$ & $\%$ \\
\hline Paramedic & 30 & $44.8 \%$ & 11 & $34.4 \%$ & 10 & $45.5 \%$ & 9 & $47.4 \%$ & 10 & $76.9 \%$ & 70 & $45.8 \%$ \\
\hline Ambulance driver & 20 & $29.9 \%$ & 11 & $34.4 \%$ & 6 & $27.3 \%$ & 5 & $26.3 \%$ & 0 & $0.0 \%$ & 42 & $27.5 \%$ \\
\hline EMS nurse & 9 & $13.4 \%$ & 6 & $18.8 \%$ & 3 & $13.6 \%$ & 2 & $10.5 \%$ & 1 & $7.7 \%$ & 21 & $13.7 \%$ \\
\hline Air ambulance pilot & 0 & $0.0 \%$ & 1 & $3.1 \%$ & 0 & $0.0 \%$ & 0 & $0.0 \%$ & 0 & $0.0 \%$ & 1 & $0.7 \%$ \\
\hline Ambulance technician & 3 & $4.5 \%$ & 0 & $0.0 \%$ & 2 & $9.1 \%$ & 0 & $0.0 \%$ & 0 & $0.0 \%$ & 5 & $3.3 \%$ \\
\hline Other & 1 & $1.5 \%$ & 1 & $3.1 \%$ & 0 & $0.0 \%$ & 0 & $0.0 \%$ & 0 & $0.0 \%$ & 2 & $1.3 \%$ \\
\hline Total & 67 & $100.0 \%$ & 32 & $100.0 \%$ & 22 & $100.0 \%$ & 19 & $100.0 \%$ & 13 & $100.0 \%$ & 153 & $100.0 \%$ \\
\hline
\end{tabular}

Table 6. Accidents by scene and year of occurrence

\begin{tabular}{|c|c|c|c|c|c|c|c|c|c|c|c|c|}
\hline & \multicolumn{10}{|c|}{ Lear } & \multirow{2}{*}{\multicolumn{2}{|c|}{ Total }} \\
\hline & \multicolumn{2}{|c|}{2008} & \multicolumn{2}{|c|}{2009} & \multicolumn{2}{|c|}{2010} & \multicolumn{2}{|c|}{2011} & \multicolumn{2}{|c|}{2012} & & \\
\hline & $\mathrm{N}$ & $\%$ & $\mathrm{~N}$ & $\%$ & $\mathrm{~N}$ & $\%$ & $\mathrm{~N}$ & $\%$ & $\mathrm{~N}$ & $\%$ & & \\
\hline Specialist ambulance with a physician & 4 & $12.5 \%$ & 2 & $13.3 \%$ & 1 & $10.0 \%$ & 2 & $20.0 \%$ & 0 & $0.0 \%$ & 9 & $12.5 \%$ \\
\hline Specialist ambulance with a physician and patient & 1 & $3.1 \%$ & 0 & $0.0 \%$ & 0 & $0.0 \%$ & 0 & $0.0 \%$ & 1 & $20.0 \%$ & 2 & $2.8 \%$ \\
\hline Basic ambulance & 19 & $59.4 \%$ & 9 & $60.0 \%$ & 2 & $20.0 \%$ & 5 & $50.0 \%$ & 2 & $40.0 \%$ & 37 & $51.4 \%$ \\
\hline Basic ambulance with a patient & 7 & $21.9 \%$ & 1 & $6.7 \%$ & 3 & $30.0 \%$ & 2 & $20.0 \%$ & 2 & $40.0 \%$ & 15 & $20.8 \%$ \\
\hline Transport ambulance & 0 & $0.0 \%$ & 2 & $13.3 \%$ & 1 & $10.0 \%$ & 0 & $0.0 \%$ & 0 & $0.0 \%$ & 3 & $4.2 \%$ \\
\hline Transport ambulance with a patient & 1 & $3.1 \%$ & 0 & $0.0 \%$ & 2 & $20.0 \%$ & 0 & $0.0 \%$ & 0 & $0.0 \%$ & 3 & $4.2 \%$ \\
\hline Air ambulance & 0 & $0.0 \%$ & 1 & $6.7 \%$ & 0 & $0.0 \%$ & 0 & $0.0 \%$ & 0 & $0.0 \%$ & 1 & $1.4 \%$ \\
\hline Hospital accident and emergency department & 0 & $0.0 \%$ & 0 & $0.0 \%$ & 1 & $10.0 \%$ & 1 & $10.0 \%$ & 0 & $0.0 \%$ & 2 & $2.8 \%$ \\
\hline Total & 32 & $100.0 \%$ & 15 & $100.0 \%$ & 10 & $100.0 \%$ & 10 & $100.0 \%$ & 5 & $100.0 \%$ & 72 & $100.0 \%$ \\
\hline
\end{tabular}


Table 7. Casualties by injury type and year of occurrence*

\begin{tabular}{|c|c|c|c|c|c|c|c|c|c|c|c|c|}
\hline & \multicolumn{10}{|c|}{ Year } & \multirow{2}{*}{\multicolumn{2}{|c|}{ Total }} \\
\hline & \multicolumn{2}{|c|}{2008} & \multicolumn{2}{|c|}{2009} & \multicolumn{2}{|c|}{2010} & \multicolumn{2}{|c|}{2011} & \multicolumn{2}{|c|}{2012} & & \\
\hline & $\mathrm{N}$ & $\%$ & $\mathrm{~N}$ & $\%$ & $\mathrm{~N}$ & $\%$ & $\mathrm{~N}$ & $\%$ & $\mathrm{~N}$ & $\%$ & $\mathrm{~N}$ & $\%$ \\
\hline Cervical spine injury & 11 & $15.9 \%$ & 5 & $16.1 \%$ & 9 & $25.0 \%$ & 5 & $31.3 \%$ & 1 & $12.5 \%$ & 31 & $19.4 \%$ \\
\hline Head injury & 12 & $17.4 \%$ & 3 & $9.7 \%$ & 1 & $2.8 \%$ & 4 & $25.0 \%$ & 1 & $12.5 \%$ & 21 & $13.1 \%$ \\
\hline Chest and trunk injury & 13 & $18.8 \%$ & 5 & $16.1 \%$ & 7 & $19.4 \%$ & 1 & $6.3 \%$ & 4 & $50.0 \%$ & 30 & $18.8 \%$ \\
\hline Multiple injuries & 14 & $20.3 \%$ & 7 & $22.6 \%$ & 8 & $22.2 \%$ & 5 & $31.3 \%$ & 1 & $12.5 \%$ & 35 & $21.9 \%$ \\
\hline Other injuries & 7 & $10.1 \%$ & 5 & $16.1 \%$ & 2 & $5.6 \%$ & 1 & $6.3 \%$ & 1 & $12.5 \%$ & 16 & $10.0 \%$ \\
\hline Poisoning & 3 & $4.3 \%$ & 0 & $0.0 \%$ & 2 & $5.6 \%$ & 0 & $0.0 \%$ & 0 & $0.0 \%$ & 5 & $3.1 \%$ \\
\hline Death & 0 & $0.0 \%$ & 3 & $9.7 \%$ & 1 & $2.8 \%$ & 0 & $0.0 \%$ & 0 & $0.0 \%$ & 4 & $2.5 \%$ \\
\hline Total & 69 & $100.0 \%$ & 31 & $100.0 \%$ & 36 & $100.0 \%$ & 16 & $100.0 \%$ & 8 & $100.0 \%$ & 160 & $100.0 \%$ \\
\hline
\end{tabular}

*The number of injuries exceeds the number of casualties since one victim may have sustained more than one injury.

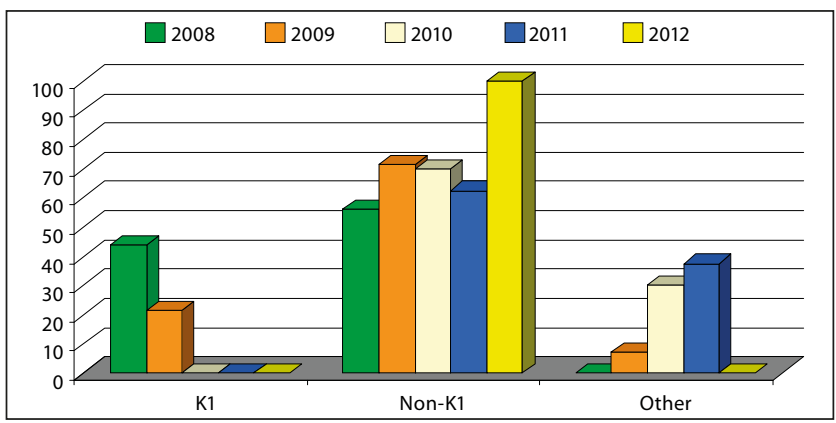

Figure 1. Accidents by type of response and year of occurrence

\section{DISCUSSION}

Between 1 January 2008 - 31 December 2012, 76 occupational accidents among the National Medical Emergency Service personnel were documented. Thirty-three (33) women and 120 men were involved in those accidents (Tab. 4). Such a big difference between the numbers of injured females and males is accounted for by the fact that males predominate in ambulance crews, additionally confirmed by classification of the casualties by job title, which shows that 70 paramedics and 21 female nurses were involved in the accidents (Tab. 5). The personnel in the 20-30 years age group accounted for $36 \%$ of all casualties (Tab. 4), which suggests that lack of experience may have been the main cause of the incidents. In the study period, as many as $48 \%$ of all male casualties were involved in occupational accidents in 2008 alone (Tab. 4). In the following years, the number of reported accidents steadily decreased. Among the female personnel, the number of accidents remained at comparable levels throughout the study period. Interestingly, most of the accidents were due, at least to some extent, to the ambulance equipment (Tab. 2).

In a study of occupational stress in paramedics conducted in the same period of time, as many as $70 \%$ of the respondents expressed their dissatisfaction with the technical condition of the ambulance equipment they had to use [7]. Table 1 shows that in 2008, 2010 and 2012 the number of casualties exceeded the number of accidents in which they were involved, but in 2009 and 2011, the opposite was observed as there were more accidents than victims. Although the incidence is known to have decreased, the available data do not explain the reason for this.
Of serious concern are cases of assault leading to bodily harm on the NEMS personnel attempting to aid patients. A survey of the psychological burden on paramedics employed in hospitals in the Podlaskie province of northeastern Poland showed that they felt exposed to the aggressive behavior, not only of patients, but also of their superiors and colleagues. Some $6 \%$ of the respondents stated that they did not like their work and $14 \%$ of those experienced overt workplace aggression from co-workers. In the same survey, approximately $30 \%$ of the respondents expressed their dissatisfaction with the equipment [8]. One year later, the results of another survey were published which investigated the degree of exposure to workplace aggression among paramedics employed in hospital accident and emergency departments and as ambulance crews. Of the emergency department employees, 59\%, 3\% and 2\% experienced overt aggression from patients, superiors and physicians, respectively, while the corresponding figures for ambulance crews were $91 \%, 8 \%$ and $5 \%$ [9].

The presented analysis demonstrates that in the study period consistently more accidents occurred on working days than on non-working days (Tab. 3), but the consequences of the incidents differed. In 2008 and 2009, the casualties mostly suffered multiple injuries. In 2010, cervical spine injuries were the most common while in 2011 they were as common as multiple injuries to other parts of the body. That changed in 2012 when traumas to the chest and trunk predominated (Tab. 7). Throughout the study period, occupational accidents occurred mostly in paramedics. In 2008, they accounted for $45 \%$ of all accidents and in 2012 for $77 \%$ (Tab. 5).

The most frequent type of incident were traffic accidents involving ambulances, which accounted for $41 \%$ of all accidents in 2008, increasing to $84 \%$ in 2012 (Tab. 2). It may be of some consolation that although the number of motor vehicles in Poland increased, the number of casualties among the NEMS personnel decreased from 51 in 2008 to 16 in 2012 (Tab. 2). Since there are no reliable and accurate data on modernizing the NEMS ambulances and their present technical condition it may be only assumed that the reduction in accident rates has been related to improved skills of ambulance drivers. Most of the incidents occurred during the non-K1 responses, i.e. not immediately life-threatening events, in both absolute terms and relative to the K1 category of responses (immediately life-threatening events). Between 2010 - 2012, no incident of this kind were reported (Fig. 2). 
Interestingly, throughout the study period, the accidents involving crews of basic ambulances were obviously more common (Tab. 6).

\section{CONCLUSIONS}

1. The growing professional experience of Poland's National Emergency Medical Services (NEMS) personnel has had a beneficial effect on the occupational injury rates, as they decreased with the length of employment.

2. Occupational accidents are definitely more common among ambulance crews than in the personnel of other organizational units of the National Emergency Medical Services.

3. Further studies should be conducted to identify the causes of occupational accidents among Emergency Medical Personnel and ways of their prevention.

\section{REFERENCES}

1. Ustawa z dnia 8 września 2006 roku o Państwowym Ratownictwie Medycznym. [Act on the Emergency Medical System of 8 September 2006] (in Polish).

2. Ustawa z dnia 30 października 2002 r. o ubezpieczeniu społecznym z tytułu wypadków przy pracy i chorób zawodowych. [Act on the Social Insurance System against the risk of occupational accidents and diseasesof 30 October 2002] (in Polish).

3. Maguire BJ, Hunting KL, Smith GS, Levick NR. Occupational fatalities in emergency medical services: a hidden crisis. Ann Emerg Med. 2002; 40(6): 625-32.

4. Ambulance Crash-Related Injuries Among Emergency Medical Services Workers - United States, 1991-2002. MMWR 2003; 52: 154-156.

5. Hinkelbein J, Schwalbe M, Genzwuerker HV. Helicopter emergency medical services accident rates in different international air rescue systems. Open Access Emergency Medicine. 2010; 2: 45-49.

6. Dąbrowska A, Dąbrowski M, Witt M. Bezpieczeństwo pracy personelu medycznego Zespołów Ratownictwa Medycznego. Anestezjologia i Ratownictwo. 2012; 6: 490-496 (in Polish).

7. Binczycka-Anholcer M, Lepiesza P. Stres na stanowisku pracy ratownika medycznego. Hygeia Public Heath. 2011; 46(4): 455-461 (in Polish).

8. Kowalczuk K, Krajewska-Kułak E, Klimaszewska K, Kondzior D. Wpływ obciążenia psychicznego pracowników zintegrowanego zespołu medycznego na zadowolenie z wykonywanej pracy. Problemy Pielęgniarstwa. 2009; 17(4): 315-320 (in Polish).

9. Kowalczuk K, Jankowiak B, Krajewska-Kułak E, Sierakowska M, Lewko J, Krajewska K, Ostapowicz-Van Damme K. Ocena stopnia narażenia ratowników medycznych na agresję w miejscu pracy. Rocznik Pomorskiej Akademii Medycznej w Szczecinie. 2009; 55(3): 76-80 (in Polish). 